\title{
Effects of Board Size, Board Composition and Dividend Policy on Real Earnings Management in the Jordanian Listed Industrial Firms
}

\author{
Yousef Shahwan ${ }^{1} \&$ Tareq Hammad Almubaydeen ${ }^{1}$ \\ ${ }^{1}$ Accounting Department, Zarqa University, Jordan \\ Correspondence: Yousef Shahwan, Accounting Department, Zarqa University, Jordan. E-mail: yshahwan@zu.edu.jo
}

Received: January 15,2020

Accepted: March 13, 2020

Online Published: July 7, 2020

doi:10.5430/ijfr.v11n4p195

URL: https://doi.org/10.5430/ijfr.v11n4p195

\begin{abstract}
Earning manipulation has been a normal transaction among the global businesses, in which business organization sees it as beneficial, thereby turning black eyes to its negative impact on the general economy. This study aimed at examining the impact of board size, Board composition and dividend policy on real earnings management in the listed Jordanian industries. 8 years data (2010 to 2018) was extracted from the audited financial reports of the selected firms. Data was analyzed using Structural Model via AMOS version 26 and SPSS version 21. The findings revealed a positive and significant effect between board size, board composition and real earning management at p-value $<0.05$ and 0.001 (two-tailed) respectively. While negative of dividend policy on REM was recorded at p-value $>0.05$ (two-tailed). This study has immensely contributed towards bridging the gap in the existing knowledge as it documented a new finding. The benefits of these findings cross over the managers, shareholders, board of directors, investors, the Jordanian government and all other relevant institute for the buildup of the healthiest industrial sector and better economy.
\end{abstract}

Keywords: corporate governance, corporate diversification, dividend policy, real earning management

\section{Research Background}

Despite the global adoption of various reporting standards, such as International Financial Reporting Standard (IFRS) and International Accounting Standards (IAS), yet unethical activities in the financial reporting are becoming order of the day. Primarily, financial reporting used to be prepared to furnish the end-users with various financial information, which enables them to make an informed financial decision especially related to the uncertainty of the future cash flow (Abed, Al-Attar \& Suwaidan, 2012). Earning management is defined as the deliberate manipulation of accounting information to improve the organizational performance by misleading the stakeholders with hope of attract potential investors to stimulate companies' income (Schipper; 1989; Healy \& Wahlen, 1999). Therefore, with the existence of ISA 37, which was strictly established to improve disclosure of true and fair view accounting information, yet managers succeeded to manage firms' earnings to their advantages (Aladwan, 2019).

Thus, managers are motivated to manipulate organizational earning to their benefits due to the importance of accounting numbers toward the prediction of future inflow (Abdulrahman \& Ali, 2006). Organizational income used to be manipulated by managers due to the perceived capital market pressure which portraits the relevance of accounting information not only to the investors but to the financial analyst for stock valuation to encourage immediate stock performance (Healy \& Wahlen, 1999). They continue to argue that among other reasons, which motivate managers to manipulate the company's earning is the use of accounting data toward monitoring and regulating the contract between the firms and stakeholders. Additionally, managers are opportunistically managing the real earnings to achieve their personal interest (Gul, Chen \& Tsui, 2003; Kassem, 2012; Rahman, Moniruzzaman, \& Sharif, 2013) and maintaining status of their stock process in the capital market (Rahman, et, al., 2013). This study is primarily conducted to examine the effect of board size, board composition and dividend policy on the real earning management in the Jordanian listed industries.

\section{Statement of Research Problem}

Unethical efforts of managers toward alternating the firms' earnings for their self-benefits among other reasons have become rampant in the global businesses, Jordanian's not excluded.various researches were conducted in the developing countries to investigate the bad habits of some managers (See, for example, Nugroho \& Eko 2011; Rudra 
\& Bhattacharjee 2012; Joshua \& Njeru 2016). Therefore, several studies have indicated a massive increase of earning management in the Jordanian industries (see, for example, Abed, et al., 2012; Alzoubi, 2016; Ibrahim \& Al Awawdeh, 2017; Alqatamin, Aribi\&Arun, 2017), although no record to date indicated that the combined effects of board size, board composition and dividend on the REM have been investigated in the Jordanian listed industries.

Accordingly, researchers like Aldeen \& Alkhatib (2016), Abu Jebril \& Al.Thuneibat (2016), Alkurdi, Tahat \& Al-mawali, (2017) and Aladwan (2019) have individually investigated the relationships between the REM and other independent variables such as corporate governance, board quality and family affiliated business, etc. As such, this study has considered it apt to address the question as do board size, board composition and dividend policy affects real earnings management in the Jordanian listed industrial firms?

\section{Research Objectives}

The primary objective of this study is to examine the effects of board size, board composition and dividend policy on real earnings management in the listed Jordanian industrial firms.

Other objectives include:

i. To study the effect of board size on the real earning management in the listed Jordanian industrial firms.

ii. To examine the relationship between the board composition and real earning management in the listed Jordanian industrial firms.

iii. To investigate the linkage between the dividend policy and real earning management in the listed Jordanian industrial firms.

\section{Literature Review and Hypotheses Development}

\subsection{Relationships Between Dividend Policy and Real Earning Management}

Dividend policy refers to the firm's financial decision regarding the proportion of the firm's earnings to be distributed in the present or future time. It serves as a base for the company's capital budgeting and pillar for capital structure. The relationship between the dividend policy and real earning management has attracted the attention of global researchers, even though there is no one direction to define the relationship with certainty. Therefore, various findings have proved a positive relationship between the dividend policy and REM while in some studies the later results were contradicted. For example, Im, Kim \& Chi (2015) revealed in their findings that there is a pressure on a firm to be consistent in dividend payout which led to high reliance on management earnings to increase the level of corporate income so as to meet the demand of stakeholders especially in the situation of losses or decline in profits. Similarly, Savov (2006) and Chansarn \& Chansarn (2016) have in their separate studies opined that large firms with huge investment tend to disclose more discretionary accrual in their reported earnings. Moreover, various findings indicated that managers attempt to engaged earning manipulation when they realize that the firm may likely not meet the required level of earning to pay the due dividend (see, Morghri \& Galogah, 2013) and looking forward to increases the earning to attract more investors (Baatour, Ben Othman \& Hussainey, 2017; Farooq, 2018; Aladwan, 2019).

In contrast, many researches have recorded a negative relationship between dividend policy and REM. For instance, the individual findings of their empirical studies, shah (2010) and Monsuru\&Adetunji (2014) were found that increasing the discretionary accruals of firm will not course an increase in the dividend payout ratio as such they conclude that earning management has no impact of the corporate dividend policy. Additionally, findings of Haider, Ali \&Saiq (2012), Aurangzeb \&Dilawe, 2012) indicated that there is no relationship between the dividend policy and REM.

H1: Dividend policy has a positive and significant effect on real earning management in the listed Jordanian industries.

\subsection{Relationships Between Board Size and Real Earning Management}

Several studies have previously indicated the role of board size in the manipulation of corporate earnings, in which a large number of the studies indicated a positive and significant effect of board size on the earning management. Abdul Rahman\& Ali (2006) revealed that board size is one of the significant elements that contributes directly to the management of corporate earnings. Previous studies have presented empirical evidence on the poor relationship between board size and effective monitoring of managers. In some instances, studies revealed that the larger the board size the lower the effectiveness of management monitoring (see, Yermack, 1996; Huther, 1997; Andres et al., 2005). Although, Dalton et al. (1999) lament that large board members contribute positively through sharing 
alternative ideas which might reduce the intent of earning management. Furthermore, past studies indicated a positive relationship between the board size and REM (for example, Abdul Rahman \& Ali, 2006).

In their empirical studies, Salihi \& Jibril, (2015), Chouaibi, Harres \& Brahim (2016), Obigbemi, Omolehinwa, Mukoro, Ben-Caleb \& Olusanmi (2016) noted a positive and significant relationship between the board size and REM, where Salihi \& Jibril mentioned that board size is one of the key governing device which directly influence earning reports and give room for earning manipulation to achieve organizational objectives. Conversely, the results of Nugroho\&Eko (2012) and Abdul Razak \& Palahuddin (2014) were individually reported a negative relationship between the board size and REM.

H2: Board size has a positive and significant effect on real earning management in the listed Jordanian industries.

\subsection{Relationships Between Board Composition and Real Earning Management}

Board composition refers to the total executive and non-executive directors on the board (i.e internal and external directors). As such various assertions were made by different scholars related to the positive or negative impacts of board composition regarding the activities of managers. However, some theories indicated the advantages of board domination by each side, where for example, Dunn (1987) supported the accession of Agency theory which was largely backed the idea of independence of the board should be dominated by non-executive directors. Therefore, protecting the interest of shareholders through proper monitoring of the managers is one of the primary responsibilities of the board of directors. As such, the composition and percentage of the board of directors' independence may affect their ability to monitor the managers (Fama \& Jensen, 1983).

Accordingly, positive effects between board composition and its independency and real earning managements ware found by several researchers (see the works of Brickley et al., 1994; Klein, 2002; Xie et al., 2003; Sonda, Bedard, \&Courteau, 2003; Peasnell et al., 2005; Kankanamage, 2015). They revealed that firms with a large number of non-executive directors are more likely to have effective control over their managers and report low earning manipulation. Conversely, some findings proved a negative effect of board composition on the real earning management. For instance, researchers like Park \& Shin (2003), Abdul Rahman \& Ali (2006), as well as Osama \& Noguer (2007), have separately established that board composition does not affect the managers' ill activities especially manipulation of firm's earnings.

H3: Board composition has a positive and significant effect on real earning management in the listed Jordanian industries.

\section{Research Methodologies}

The present study is designed to be descriptive to adequately examine the effects of the board size, board composition and dividend policy on the real earning management in the Jordanian listed industrial firms.

The population of this study encompasses the entire listed Jordanian industrial companies. The selection of the Jordanian industrial sector was based on the fact that it is the biggest and most crucial sector which contributes largely to the Jordanian economic growth and development (Aladwan, 2019). Moreover, the population size under study constitutes a total of 78 firms in which 27 firms were deleted based on the following criteria:

i. That the companies must be listed in the Amman Stock Exchange from 2010 to 2018;

ii. That the companies have never been delisted from ASE;

iii. That the companies must have a complete 8 years audited financial reports, and

iv. That the financial statement of the companies must disclose the number of its board of directors.

The total sample size becomes 51 firms which consist of 149 observations. The data was obtained from the audited financial statements available on the ASE website and companies' websites.

\subsection{Variables Under Study and Their Measurements}

Four variables were used in this study, in which Board Size (BrdSiz), Board Composition (BrdCmp), and Dividend Policy (DivPopl) were considered as independent variables. While Real Earning Management (REM) is the dependent variable. Control variables were also used, which include audit quality (AdtQlt) and Firm Size (FrmSiz).

In order to measure the relationship between the exogenous and the endogenous variables, Board size is measured based on the total number of the board as used in the prior studies (see, for example, Kassinis, Nil, Egbide\& Moses, 2011; Al Daoud, Ismail, \& Lode, 2014), board composition is measured in relation to the total proportion of non-executive directors on the Board as used by Webb, (2004). Moreover, in line with several studies dividend 
policy is measured using dividend payout ratio (DR) as suggested by Aladwan (2019) that dividend ratio measured the level of dividend distribution.

The dependent variable, which is REM was measured using the modified Jones model as proposed by Dechow et al., (1995). DisAcc was used as a proxy of REM in which Kothari et al. (2005) suggested that the behavior of firms' earning management is the function of discretionary accruals (DisAcc). Therefore, the function of DisAcc is expressed as:

Hence Discretionary Accrual (DisAccit) is determined by deducting the Non-Discretionary Accrual (NDisAccit) from the Total Accrual (TtAccit) as stated below:

$$
\text { DisAcc }_{i t}=\text { TtAcc }_{i t}-\text { NDisAcc }_{i t}
$$

(Equation 1)

\section{Therefore:}

$\mathrm{TtAcc}_{\mathrm{it}}=$ Net Income (NI) - Cash Flow From Operating Activities (CFOA)

(Equation 2)

$$
\underline{\text { NDisAcc }_{i t}}=\beta_{1} 1+\beta_{2} \Delta \text { REVit }-\triangle \text { RECit }+\beta_{3} \mathrm{PPE}_{\mathrm{it}}+\varepsilon_{1}
$$

$$
\mathrm{TA}_{\mathrm{it}-1} \mathrm{TA}_{\mathrm{i}, \mathrm{t}-1}
$$

The below equation was used to determine the individual firms' accruals:

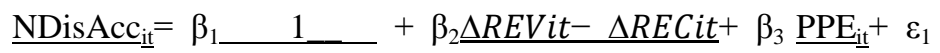

(Equation 4)

$$
\mathrm{TA}_{\mathrm{it}-1} \mathrm{TA}_{\mathrm{i}, \mathrm{t}-1} \mathrm{~T} A_{i, t-1} \mathrm{~T} A_{i, t-1}
$$

DisAcc denotes Discretionary Accruals; TtAcc means Total Accruals; NDisAcc refers to Non-Discretionary Accrual; TA means Total Assets; $\triangle \mathrm{REV}$ means change in revenues from the previous year; $\triangle \mathrm{REC}$ represents change in Receivables from the preceding year; PPE denotes Property, Plant and Equipment. Accordingly, parameters and error term used in the regressions were presented as $\beta$ and $\varepsilon$ respectively.

\subsection{Model Specification}

$$
\mathrm{REM}=\mathrm{B}_{0}+\beta_{1}(\mathrm{DivPol})+\beta_{2}(\mathrm{BrdSiz})+\beta_{3}(\mathrm{BrdCmp})+\beta 4(\text { AudQly })+\beta 5(\text { FrmSiz })+\mathrm{e}_{1}
$$

\section{Data Presentation}

\subsection{Regression Path}

\subsubsection{Unstandardized Regression Path}

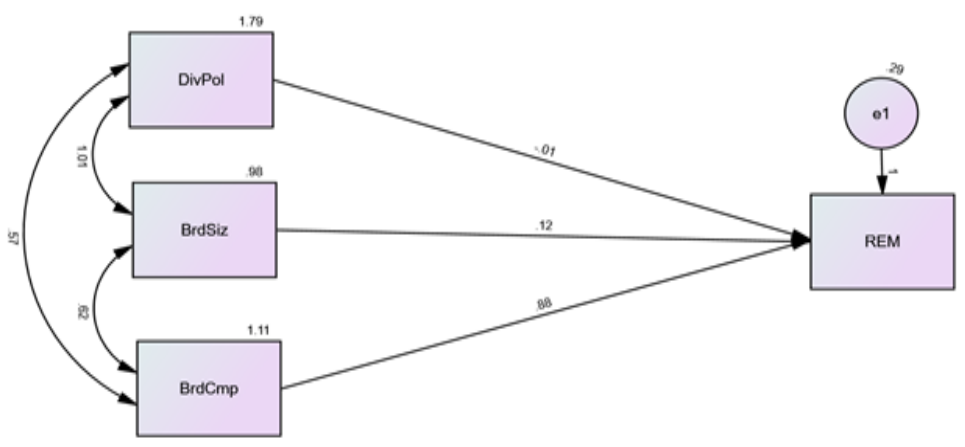

Figure 1. Unstandardized structural regression estimate (AMOS 26)

Table 1. Unstandardized regression weights

\begin{tabular}{cllccc}
\hline \multicolumn{2}{l}{ Regression Path } & Estimate & Standard Error & Critical Ratio & P-value \\
\hline REM & BrdSiz & 0.119 & 0.054 & 2.19 & 0.028 \\
REM & DivPol & -0.008 & 0.035 & -0.24 & 0.811 \\
REM & BrdCmp & 0.875 & 0.036 & 24.277 & $* * *$
\end{tabular}

Source: Data Analysis, 2019 via AMOS version 26 \& SPSS version 21 
The Table 1 above indicated that, when individually board size and board composition go up by 1 the real earning management goes up by .119 and .875 at estimated standard errors of .054 and .036 respectively. The estimated regression weight of 2.190 and 24.277 were arrived as $\mathrm{z}=.119 / .054$ and $.875 / .036$ standard error above zero. Therefore, the probability of attaining a critical ratio as large as 2.190 and 24.277 in absolute value is less than 0.05 and 0.001 each. This indicated that the regression weight of board size and board composition in the prediction of real earning management is significantly different from zero at p-value less than 0.05 and 0.001 level (two-tailed).

Additionally, real earning management goes up by 1 as dividend policy goes down by 0.008 at an estimated standard error 0.035 . The critical ratio of -0.240 was gotten as $\mathrm{z}=-0.008 / 0.035$ standard error lower than zero. As such, the probability of getting critical ration as large as -0.240 in an absolute value is 0.811 . In other word, the regression weight coefficient for Dividend policy in the prediction of real earning management is insignificantly different from zero at p-value greater than 0.05 level (two-tailed).

\subsubsection{Standardized Regression Path}

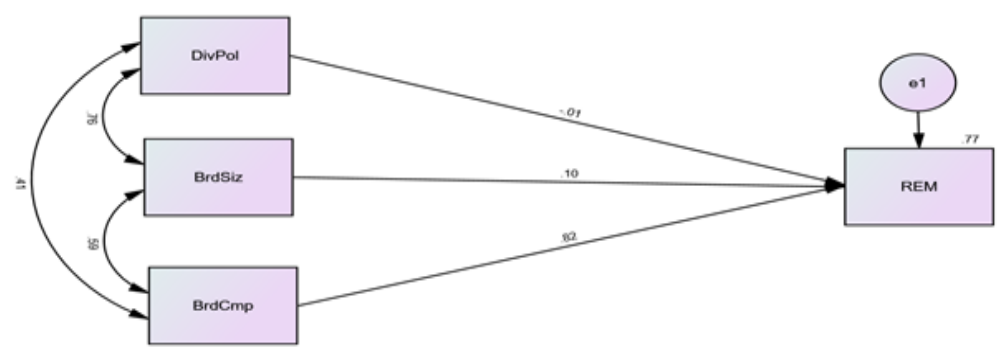

Figure 2. Standardized structural regression estimate

The above figure indicates the result of structural regression analysis in which the value of squared multiple correlation (R2) is depicted as 77. This shows that the level of exogenous variables' contribution to the prediction of the endogenous variable stood at $77 \%$.

Table 2. Standardized regression weights

\begin{tabular}{ll}
\hline Regression Path & Estimate \\
\hline REM BrdSiz & .105 \\
\hline REM & -.010 \\
\hline REM & .817 \\
\hline
\end{tabular}

Source: Data Analysis, 2019 via AMOS version 26 \& SPSS version 21

The table above portraits the level of standard deviation of exogenous variables in the prediction of the endogenous variable under study. It is shown in the table above that when BrdSiz and BrdCmp go up by 1 standard deviation respectively, REM will consequently go up by 0.105 and 0.0817 standard deviation. Also, when DivPol goes up by 1 standard deviation, REM will go down by 0.010 standard deviation.

\subsection{Testing Research Hypotheses and Discussion of Findings}

Table 3. Estimated coefficient of unstandardized regression path

\begin{tabular}{llllll}
\hline Regression Path & Std. Beta & Std. Error & C.R. & P-Value & Decision \\
\hline DivPolREM & -0.01 & 0.035 & -0.240 & 0.881 & Not Supported \\
\hline BrdSiz $\longrightarrow$ REM & 0.12 & 0.054 & 2.190 & 0.028 & Supported \\
\hline BrdCmp $\rightarrow$ REM & 0.88 & 0.036 & 24.277 & $* * *$ & Supported \\
\hline
\end{tabular}

Source: Data Analysis, 2019 via AMOS version 26 \& SPSS version 21 


\subsubsection{Discussion of Research Findings}

Hypothesis 1, which specified that there is a significant and positive effect between the dividend policy and real earning management in the Jordanian listed industries is not supported at p-value higher than 0.05 (two-tailed). In other words, the hypothesis is rejected at p-value $>0.05$ (two-tailed). Hence, this finding was attuned with the previous results of shah (2010), Haider et al. (2012), Aurangzeb \&Dilawe (2012) and Monsuru\&Adetunji, (2014). In conjunction with their findings, this result was revealed that an increase in the discretionary accruals of the firm does not necessarily instigate growth or otherwise in the dividend policy. However, this finding opposed the results of Morghri\&Galogahv (2013), (Baatour et al, 2017), Farooq (2018) and Aladwan (2019).

From the table above it can be seen that hypothesis 2, which stated that there is a significant and positive effect between the board size and real earning management in the Jordanian listed industries is supported at a p-value less than 0.05 (two-tailed). The finding is attuned with previous researches such as (Abdul Rahman\& Ali, 2006; Abed, et al., 2012; Obigbemi, Omolehinwa, Mukoro, Ben-Caleb \&Olusanmi (2016). The result indicated that the higher the board size the stronger the board toward preventing manipulation of the organizational earnings through sharing various alternative experiences. Therefore, the finding has contradicted the results of Xie et al. (2003) Peasnell et al. (2005) and Abbott et al. (2000).

Accordingly, hypothesis 3 stated that board composition has positively and significantly affect real earning management of the Jordanian listed industries. Therefore, the hypothesis is strongly supported at P-value less than 0.001 (two-tailed). Moreover, this finding concurred with the individual findings of Klein (2002) and Sonda et al. (2003). The finding indicated that a large number of non-executive directors on the board and a higher percentage of independency may significantly lead to effective monitoring and control over the managers' activities hence prevent them from manipulating organizational income. Relatively, this finding contradicted the result of Park \& Shin (2003), Abdul-Rahman\& Ali (2006) and Osama \&Noguer (2007) where they established a positive effect between the variables in question.

\section{Conclusion and Recommendations}

This study was conducted to evidently explore the effects of the board size, board composition and dividend policy on the real earning management in the listed Jordanian industries. The study revealed that board size and board composition have positive and significant effects on the real earning management in the Jordanian listed industries at a significant p-value of less than 0.05 and 0.001 (two-tailed) respectively. While the finding labeled that dividend, policy does not affect real earning management in the Jordanian listed industries at an insignificant $p$-value higher than 0.05 (two-tailed).

This study contributes to the literature of earnings management through documenting evidence that political influence and duality of the roles between executive and non-executive board of directors help to increase earnings management practices and proved the negative effects of dividend policy on the REM. This study adds values to the existing body of knowledge since it denoted the collective effects of board size and board composition on the REM and reaffirmed the assertion of Divided Irrelevance Theory of Modigliani and Miller as the finding purported a negative effect of dividend policy on the REM.

Henceforth, based on these findings it is recommended that Jordanian industries should consider increasing the proportion of non-executive directors in their board and their independence so as to remedy the ill actions of managers (earning manipulation). Also, the Jordanian industries should comprehend that the larger the board size the lower the power of the managers to makes certain financial decision which will jeopardize the going-concern of the firm for their personal interest. It is suggested that both existing and potential investors should critically examine the Audited financial reports of the interested firm and consider both statistical and non-statistical information in making their decision. Since the industrial sector is one of the key sectors to the Jordanian economy, it is recommended that the Jordanian government should devise an informed method of ensuring the reliability of financial reports of the listed industrial companies. It is also recommended that both external and internal auditors of the listed Jordanian industries should be encouraged to strictly ensure that the prepared financial reports of the listed Jordanian industries are in total compliance with relevant accounting standards.

\section{Suggestions for Future Study}

Finally, this study is limited to examining the possible impacts of board size, board composition and dividend policy on the real earning management in the listed Jordanian industries due to the wide range of the area under study and difficulty toward measuring the management behaviors which serves as a hoodlum to this study. As such future study may wish to be conducted on the investigation of moderating role of an audit committee in limiting the effects of political influence on the management of the firm's earnings. Also, other microeconomic variables can be used to 
assess the impact of REM on corporate profitability especially in the other sectors of Jordanian economy.

\section{Acknowledgements}

This research was funded by Deanship of Research in Zarqa University. I would like to acknowledge Zarqa University who provided insight and expertise that greatly assisted the research.

\section{References}

Abdul Rahman, R., \& Ali, F. (2006). Board, Audit committee, Culture and Earnings Management: Malaysian Evidence. Managerial Auditing Journal, 21(7), 783-804. http://doi.org/10.1108/02686900610680549

Abed, S., Al-Attar, A., \& Suwaidan, M. (2012). Corporate governance and earnings management: Jordanian evidence. International Business Research, 5(1), 216-221.https://doi.org/10.5539/ibr.v5n1p216

Abu Jebril, A.Y., \& Al.Thuneibat, A. (2016). The impact of internal audit on earnings management in the industrial companies listed in Amman Stock Exchange. Jordan Journal of Business Administration, 12(4), 789-811. https://doi.org/10.12816/0034969

Ajide, F. M., \& Aderemi, A. A. (2014). The effects of earnings management on dividend policy in Nigeria: an empirical note. The SIJ Transactions on Industrial, Financial \& Business Management (IFBM), 2(3), 145-152.

Aladwan, M. (2019). Accrual Based and Real Earning Management Association with Dividends Policy "The Case of Jordan". Italian Journal of Pure and Applied Mathematics, 691-707. Retrieved from https://www.researchgate.net/publication/329718606

Alkurdi, A., Tahat, Y., \& Al-mawali, H. (2017). The effect of governance attributes on corporate dividend payouts policy: evidence from Jordan. International Journal of Corporate Governance, 8(3-4), 313-334. https://doi.org/10.1504/IJCG.2017.089817

Alqatamin, R. M., Aribi, Z. A., \& Arun, T. (2017). The effect of the CEO's characteristics on EM: Evidence from Jordan. International Journal of Accounting and Information Management, 25(3), 356-375. https://doi.org/10.1108/IJAIM-10-2016-0099

Al-Ramahi, N., Barakat, A., \& Shahwan, Y. (2014). The impact of corporate governance principles application on financial performance of public shareholding companies listed in Amman stock exchange. European Journal of Accounting Auditing and Finance Research, 2(6), 100-117.

Al-Sraheen, D. A. D., \& Alkhatib, K. (2016). Proposing a model for limiting earning management practices: The case of Jordanian listed firms. Corporate Board: Role, Duties and Composition, 12(3), 81-84. https://doi.org/10.22495/cbv12i3art9

Alzoubi, E. S. S. (2016). Disclosure quality and earnings management: Evidence from Jordan. Accounting Research Journal, 29(4), 429-456. https://doi.org/10.1108/ARJ-04-2014-0041

Baatour, K., Ben Othman, H., \& Hussainey, K. (2017). The effect of multiple directorships on real and accrual-based earnings management: Evidence from Saudi listed firms. Accounting Research Journal, 30(4), 395-412. https://doi.org/10.1108/ARJ-06-2015-0081

Brickley, J. A., Coles, J. L., \& Terry, R. L. (1994). Outside Directors and Adaption of Poison Pills. Journal of Financial Economics, 35, 371-390. http://doi.10.1610/0403-405X(94)90038-8

Chansarn, S., \& Chansarn, T. (2016). Earnings Management and Dividend Policy of Small and Medium Enterprises in Thailand. International Journal of Business and Society, 17(2), 307-328. https://doi.org/10.33736/ijbs.527.2016

Dechow, P. M., Sloan, R. G., \& Sweeney, A. P. (1995). Detecting earnings management. The Accounting Review, 70(2), 193-225.

Dilawer, T. (2012). Earning management and dividend policy: evidence from Pakistani textile industry. International Journal of Academic Research in Business and Social Sciences, 2(10), 362.

Fama, E. F., \& Jensen, M. C. (1983). Separation of ownership and control. The Journal of Law and Economics, 26(2), 301-325. https://doi.org/10.1086/467037

Farooq, O., Shehata, N., \& Nathan, S. (2018). Dividend policy and informativeness of reported earnings: evidence from the MENA region. International Review of Finance, 18(1), 113-121. https://doi.org/10.1111/irfi.12124

Gul, F. A., Chen, C. J., \& Tsui, J. S. (2003). Discretionary accounting accruals, managers' incentives, and audit fees. Contemporary Accounting Research, 20(3), 441-464. https://doi.org/10.1506/686E-NF2J-73X6-G540 
Haider, J., Ali, A., \& Sadiq, T. (2012). Earning management and dividend policy: Empirical evidence from Pakistani listed companies. European Journal of Business and Management, 4(1), 83-90.

Healy, P., \& Wahlen, J. (1999).A review of the earnings management literature and its implications for standard setting. Accounting Horizons, 13(14), 365-383. https://doi.org/10.2308/acch.1999.13.4.365

Huther, J. (1997). An Empirical Test of the Board Size on the Firm Efficiency. Economic Letters, 54, 259-264. http://doi.org//10.1016/ S0165-1765(97)000.35-9

Ibrahim, A., \& Al Awawdeh, H. (2017). Earnings management and its impact on accounting earnings quality-Experimental study on the Jordanian industrial public shareholding companies. Jordan Journal of Business Administration, 13(2), 161-179. https://doi.org/10.12816/0040701

Im, C. C., Kim, J. H., \& Choi, M. K. (2015). Dividend policy and earnings management: Based on discretionary accruals and real earnings management. International Journal of $u$-and e-Service, Science and Technology, 9(2), 137-150. https://doi.org/10.14257/ijunesst.2016.9.2.15

Joshua, K. M., \&Njeru, A. (2016). Determinants of Earnings Management Practice among Non-Listed Firms in the Motor Industry in Kenya. International Journal of Science and Research, 5(9), 623-633.

Kankanamage, C. A. (2015). The relationship between board characteristics and earnings management: Evidence from Sri Lankan listed companies. Kelaniya Journal of Management, 4(2), 36-43. https://doi.org/10.4038/kjm.v4i2.7499

Kassem, R. (2012). Earnings management and financial reporting fraud: can external auditors spot the difference?. American Journal of Business and Management, 1(1), 30-33. https://doi.org/10.11634/21679606170646

Klein, A. (2002). Audit committee, board of director characteristics, and earnings management. Journal of Accounting and Economics, 33(3), 375-400. https://doi.org/10.1016/S0165-4101(02)00059-9

Moghri, A. E., \& Galogah, S. S. (2013). Effect of earnings management on dividend policy: evidence from Tehran Stock Exchange. World of Sciences Journal, 1(14), 58-65.

Nugroho, B. Y., \& Eko, U. (2012). Board characteristics and earning management. Bisnis \& Birokrasi Journal, 18(1), $1-10$.

Obigbemi, I. F., Omolehinwa, E. O., Mukoro, D. O., Ben-Caleb, E., \& Olusanmi, O. A. (2016). Earnings management and board structure: Evidence from Nigeria. SAGE Open, 6(3). https://doi.org/10.1177/2158244016667992

Rahman, R. A., \& Ali, F. H. M. (2006). Board, audit committee, culture and earnings management: Malaysian evidence. Managerial Auditing Journal, 21(7), 783-804. https://doi.org/10.1108/02686900610680549

Rudra, T., \& Bhattacharjee, C. D. (2012). Does IFRs influence earnings management? Evidence from India. Journal of Management Research, 4(1), 1. https://doi.org/10.5296/jmr.v4i1.849

Salihi, A. A., \& Jibril, R, S. (2015). The effect of board the size and audit committee the size on earnings management in Nigerian consumer industries companies. International Journal of Innovative Research and Development, 4(3), 84-91.

Savov, S. (2006). Earnings management, investment, and dividend payments. Journal of Financial Economic, 12, 198-236. https://doi.org/10.2139/ssrn.917680

Shah, S. Z., Yuan, H., \& Zafar, N. (2010). Earnings management and dividend policy: An empirical comparison between Pakistani listed companies and Chinese listed companies. International Research Journal of Finance and Economics, 35(1), 51-60.

Shahwan, Y., \& Mohammad, N. R. (2016). Descriptive Evidence of Corporate Governance \& OECD Principles for Compliance With Jordanian Companies. Journal Studia Universitatis Babes-Bolyai Negotia.

Sonda, M. C., Bedard, J., \& Courteau, L. (2003). Corporate Governance and Earnings Management. Working Paper. Retrieved from http/paper.ssrn.com

Xie, B., Davidson III, W. N., \& DaDalt, P. J. (2003). Earnings management and corporate governance: the role of the board and the audit committee. Journal of Corporate Finance, 9(3), 295-316. https://doi.org/10.1016/S0929-1199(02)00006-8

Yermack, D. (1996). Higher Market Valuation of Companies with a Small Board of Directors. Journal of Financial Economics, 40, 185-2. https://doi.org/10.1016/0304-405X(95)00844-5 